\title{
Amelioration of Motor Behavioral Aberrations and Cerebellar Abnormalities by Ethanol Leaf Extract of Balakat Tree (Ziziphus talanai (Blanco) Merr.) in Valproic Acid Mice Model of Autism
}

\author{
Aaron Carl Tejano', \\ Lourdes Fatima David ${ }^{1}$, \\ Angelo Bañares ${ }^{1,2}$, \\ Renato Dela Peña, Jr. ${ }^{3,4}$, \\ Angelico Reyes ${ }^{1,5^{*}}$
}

${ }^{1}$ Department of Natural Sciences and Mathematics, Institute of Arts and Sciences, Mabalacat City College, Mabalacat City, Pampanga, Philippines ${ }^{2}$ Department of Energy Science and Technology, Energy and Environment Fusion Technology Center, Myongji University, Myongji-ro 116, Cheoin-gu, Yongin, Gyeonggi-do, Korea ${ }^{3}$ Chemistry and Life Sciences Department, Manila Tytana Colleges, Pres. Diosdado Macapagal Blvd., Pasay City, Metro Manila, Philippines

${ }^{4}$ Science Education Department, Br. Andrew Gonzalez College of Education, De La Salle University, Taft Ave. 2401, Malate, Manila, Metro Manila, Philippines

${ }^{5}$ Biology Department, College of Science, De La Salle University, Taft Ave. 2401, Malate, Manila, Metro Manila, Philippines

*Corresponding author:

Angelico Reyes

angelico_reyes@dlsu.edu.ph

\section{KEYWORDS:}

Ziziphus talanai (Blanco) Merr.; Ethanol leaf extract; Ameliorative agent; Autism; Valproic acid

https://www.pharmacy.mahidol.ac.th/journal/ (C) Faculty of Pharmacy, Mahidol University (Thailand) 2020

\begin{abstract}
Exposure of the brain to Valproic Acid (VPA), an antiepileptic drug, during critical periods of postnatal brain development can lead to motor behavioral and neuroanatomical anomalies congruent with autism-spectrum disorders (ASD) in people diagnosed with autism. Loss of Purkinje cells (PC) in the cerebellum and retardation and regression in acquired motor behaviors are the main diagnostic features of autism pathophysiology. Since autism afflicts 4 in 10,000 children globally, there have been ongoing efforts to address autism by means of ameliorative agents such as bioactive compounds from plants. Preliminary phytochemical screening of the ethanol leaf extract of Ziziphus talanai (Balakat tree) revealed the presence of bioactive chemicals with neuroprotective potentials. This study employed 8 mice pups distributed into 4 groups that received the treatments on postnatal day (PND) 14-16: $\mathrm{T}$ - received no treatment; $\mathrm{T}+$ received VPA at $400 \mathrm{mg} / \mathrm{kg}$ bw; T1 received $400 \mathrm{mg} / \mathrm{kg}$ bw of VPA and $300 \mathrm{mg} / \mathrm{kg}$ bw ethanol leaf extract of $Z$. talanai (ELEZT); and T2 received VPA at $400 \mathrm{mg} / \mathrm{kg}$ bw and $400 \mathrm{mg} / \mathrm{kg}$ bw ELEZT. $\mathrm{T}+$ exhibited retardation in negative geotaxis maturation, regression of acquired skill for mid-air righting reflex, and density reduction in Purkinje cell layer. ELEZT administered at $300-400 \mathrm{mg} / \mathrm{kg}$ bw to T1 and T2 have resulted in comparable significant improvements in neurobehavioral retardation and regression and cytological structure of the PC cells in contrast with $\mathrm{T}+$. These results suggest that the ELEZT possesses ameliorative potentials against behavioral aberrations and altered cerebellar histology in VPA-induced postnatal autism in murine models.
\end{abstract}

\section{INTRODUCTION}

Autism is a developmental disorder affecting approximately 4 in 10,000 children and is much common in males than in females in a ratio of $\sim 4: 1$. It has been reported that the incidence of autism has been increasing exponentially over the last decade ${ }^{1,2}$. Regression, retardation, and intrusion of behaviors are indications 
of persons diagnosed with autism. Genetic factors and early environmental exposure to toxicants during gestation result in the development of autism in individuals due to neuronal cell death or post-natal brain damage ${ }^{3,4,5}$. A prominent feature present in the pathological studies of autism is the evidence of reduced number of Purkinje cells (PCs) in the posterolateral cerebellar cortex ${ }^{1,6,7}$. Valproic acid (VPA) is used in the treatment of psychiatric conditions by its modulation of GABA neurotransmission ${ }^{8}$. Studies on animal models demonstrated behavioral impairments upon postnatal exposure to $\mathrm{VPA}^{9}$. Literature indicates that phenolic phytochemicals can serve as ameliorative agents by preventing oxidative stress and inflammation ${ }^{10}$. It has been shown that plants containing ameliorative agents can mitigate autism-like behavior ${ }^{1,}{ }^{11}$. Antioxidants are abundant in the genus Ziziphus, to which Ziziphus talanai belongs ${ }^{12}$. Previous phytochemical analysis of $Z$. talanai has confirmed the presence of phenolic compounds in its ethanolic leaf extract ${ }^{13}$.

There is a paucity of data concerning the ameliorative potentials of $Z$. talanai against VPAinduced motor behavioral aberrations and cerebellar abnormalities. This study, therefore, was a seminal evaluation of the ameliorative potentials of $Z$. talanai against motor behavioral aberrations and cerebellar abnormalities due to VPA-induced autism in mice model.

\section{MATERIALS AND METHODS}

\subsection{Treatment groups}

The study investigated the ameliorative activity of varying concentrations of the crude ethanolic leaf extract of $Z$. talanai (ELEZT) against aberrations in motor behaviors and cerebellar architecture in mice offsprings postnatally exposed to VPA to induce autism. Table 1 gives a complete description of the treatment groups.

Table 1. Treatment groups

\begin{tabular}{cl}
\hline Treatment Groups & Treatments \\
\hline $\mathrm{T}-($ Negative Control) & Mice pups were treated with distilled water $(300 \mu \mathrm{l} / \mathrm{kg} \mathrm{bw})$ \\
\hline $\mathrm{T}+($ Positive Control) & Mice pups were treated with VPA $(400 \mathrm{mg} / \mathrm{kg} \mathrm{bw})$ \\
\hline $\mathrm{T} 1$ & Mice pups were treated with VPA $(400 \mathrm{mg} / \mathrm{kg} \mathrm{bw})$ and ELEZT $(300 \mathrm{mg} / \mathrm{kg} \mathrm{bw})$ \\
\hline $\mathrm{T} 2$ & Mice pups were treated with VPA $(400 \mathrm{mg} / \mathrm{kg} \mathrm{bw})$ and ELEZT $(400 \mathrm{mg} / \mathrm{kg} \mathrm{bw})$ \\
\hline
\end{tabular}

\subsection{Plant material}

Adult leaves of $Z$. talanai were obtained from trees situated along the periphery of a recreational park located in Mabiga, Mabalacat City, Pampanga, Philippines. Collected leaves of $Z$. talanai were sent to Jose Vera Santos Memorial Herbarium, Institute of Biology, College of Science, University of the Philippines, Diliman, Quezon City, Philippines for taxonomic authentication. The Herbarium authenticated that the sample belongs to Ziziphus talanai (Blanco) Merr.

\subsection{Experimental animals}

All measures in this study in relation to the experimental animals were performed in accordance with the procedures specified in the Guidelines for the Care and Use of Mammals in Neuroscience and Behavioral Research published by the National
Research Council ${ }^{14}$. A total of 8 mice pups were used as animal models in the study. For the four (4) treatment groups, two (2) replicates of experimental animals were assigned. The pups were given birth by reproductively mature female mice mated with reproductively mature males purposely for this study. Ten (10) pairs of parent mice were purchased from the Zoology Department, Institute of Biology, College of Science, University of the Philippines, Diliman, Quezon City, Philippines. After purchase, the parent mice were given two (2) weeks to acclimatize to the new environment. Reproductively mature females and males were placed in separate improvised plastic cages with dimensions of 0.5 $\mathrm{x} 0.5 \times 0.5 \mathrm{~m}$. Then the females and males were randomly selected for mating purposes. Upon the birth of mice pups, they were weighed using a digital weighing scale. Two significant figures were used 
in the measurement of various parameters. The improvised square cages were made up of wood and plastic, measuring $0.5 \times 0.5 \times 0.5 \mathrm{~m}$ for the containment of each mouse litter along with the mother. This was done to prevent the animals from hurting each other and stress. Dried wood pulps were provided as bedding for the mice. The mice were maintained in an environment with 12/12-hour light/dark cycle at room temperature. They were given commercial grade pigeon pellets and water ad libitum. Hygienic conditions and proper ventilation were maintained ${ }^{13,14}$.

\subsection{Preparation of ethanol leaf extract}

Leaves of $Z$. talanai were air-dried for seven (7) days in a well-ventilated room at room temperature away from direct sunlight to avoid the loss of valuable bioactive compounds. Dried leaves were cut into small fragments and were homogenized into a fine powder using an electric blender and sieved to separate coarser materials. Powdered leaves were soaked in two (2) L of $70 \%$ ethanol for 72 hours at room temperature. Separation of solid and liquid portions was done using Whatman filter paper no.1. To eliminate the solvent ethanol, the liquid part of the solution was sent to the Center for Research and Development of Angeles University Foundation, Angeles City, Pampanga, Philippines for rotary evaporation. The treatment dosages of $300 \mathrm{mg} / \mathrm{kg}$ and $400 \mathrm{mg} / \mathrm{kg}$ of the leaf extract for administration were computed based on the body weight of the mice pups. Samples were stored in the refrigerator until use ${ }^{13}$.

\subsection{Percentage yield}

$\left(M_{2} / M_{1}\right) X 100$, wherein $M_{2}$ is the mass of the semi-solid portion of the ethanol extract and $M_{1}$ is the mass of leaves prior to extraction. $\mathrm{M}_{2}$ is $57.32 \mathrm{~g}$ and $\mathrm{M}_{1}$ is $825.36 \mathrm{~g}$. Percentage yield $=57.32 \mathrm{~g} / 825.36 \mathrm{~g} \mathrm{X} 100=6.94 \%$.

\subsection{Preparation of VPA}

VPA syrup (250 mg per $5 \mathrm{~mL}$ ), commercially available as Depakene, was purchased with a prescription from Mercury Drug Store in Dau, Mabalacat City, Pampanga, Philippines. One (1) mL of the VPA syrup contains $50 \mathrm{mg}$ of VPA, and 8 $\mathrm{ml} / \mathrm{kg}$ (bw) was the calculated amount to achieve the dosage of $400 \mathrm{mg} / \mathrm{kg}(\mathrm{bw})^{9}$. The mice pups were weighed using a digital weighing scale and the volume of administered VPA was computed based on the aforementioned dosage.

\subsection{Administration of treatments}

The administration of treatments was done via oral intragastric technique for three (3) days to induce autism-like features in mice pups. Administration of VPA syrup was conducted from postnatal day (PND) 14 until PND 16. The administration of ELEZT was undertaken six (6) hours after the administration of VPA syrup to allow for the half-life of the $\mathrm{VPA}^{3,11,9}$.

\subsection{Motor behavioral assessments}

\subsubsection{Negative geotaxis}

The assessment of the negative geotaxis of the experimental mice pups was done by placing them on a $45^{\circ}$ slope with their head pointing down the incline. The time it takes for the mice pups to turn $180^{\circ}$ axially so that they are facing upward to the incline was recorded. A maximum time of thirty (30) seconds was given to the mice pups in each trial. This test was performed on PND $14-15^{9,11}$.

\subsubsection{Hanging grip wire test}

This test evaluates the muscle strength of mice pups to hold their body weight using their forelimbs and hindlimbs upon placement on an inverted grid wire surface measuring $30 \mathrm{~cm} \mathrm{x}$ $18 \mathrm{~cm}$ with $1.2 \mathrm{~cm}$ grid squares. The latency of the mice pups to let go and fall off the inverted grid wire was recorded with a maximum of 30 seconds for each trial. The test was performed on PND 14-15.

\subsubsection{Mid-air righting reflex}

Mid-air righting reflex was performed on PND 14-16 by dropping the offspring mice upside down from a height of thirty (30) $\mathrm{cm}$ onto a padded surface. The time of rostrocaudal movements and the ability to land by their hind limbs were observed and recorded as an index 9 .

\subsection{Histopathological analysis of cerebellar tissue}

Cerebellum of the mice pups was fixed 
in $30 \%$ sucrose phosphate buffer overnight. This was prepared by dissolving three (3) gm of sucrose in seven (7) $\mathrm{ml}$ of phosphate buffer. The samples were sent to High Precision Diagnostics in Angeles City, Pampanga, Philippines for tissue slide preparation. Briefly, $1 \mathrm{~mm}^{3}$ tissue blocks were cut from the cortex of the cerebellar hemispheres, processed and routinely embedded in paraffin. Thin sections of cerebellum were stained with haemotoxylin and eosin (H\&E) and examined under the light microscope ${ }^{15}$. The prepared slides of mice pups' cerebellum were observed under scanner (40x), low power (100x), and high power (400x) objectives. Alterations of the cerebellar cytoarchitecture were assessed at random microscopic fields.

\subsection{Statistical analysis}

Statistical analysis of the mean latency scores of negative geotaxis and hanging wire grip test on PND 14-15 was performed using One-Way Analysis of Variance (ANOVA), followed by Tukey HSD post-hoc test. A $p$-value less than .05 was accepted as statistically significant. Statistical treatment was done using GraphPad Prism version 6 (available online at www.graphpad.com).

\section{RESULTS}

\subsection{Effect of ELEZT on negative geotaxis}

Figure 1 shows that $\mathrm{T}$ - mice pups have a very low mean latency score signifying normal geotactic behavior. $\mathrm{T}+$ mice pups showed high mean latency score suggesting that the mice have autism-like features. Further, mice pups of T1 scored low mean latency scores on the negative geotaxis test. Mice pups on T2 scored much lower mean latency score on the negative geotaxis test. With an $\mathrm{F}_{(3,4)}=10.29, p=0.0234$, there is a significant difference in the mean latency scores of treatment groups. The results clearly indicate that the treatments of the mice pups on PND 14 have a clear effect on the latency scores. T- and $\mathrm{T} 2$ had statistically lower mean latency score than $\mathrm{T}+$. T-, T1, and $\mathrm{T} 2$ had comparable mean latency scores. This suggests that VPA had induced aberration on the negative geotaxis of $\mathrm{T}+$ mice pups as indicated by the statistically higher mean latency score. Further, T2, which received $400 \mathrm{mg} / \mathrm{kg}$ bw of ELEZT, had statistically lower mean latency score than $\mathrm{T}+$, which is comparable with $\mathrm{T}$-, suggesting that ELEZT had ameliorated the effects of VPA.

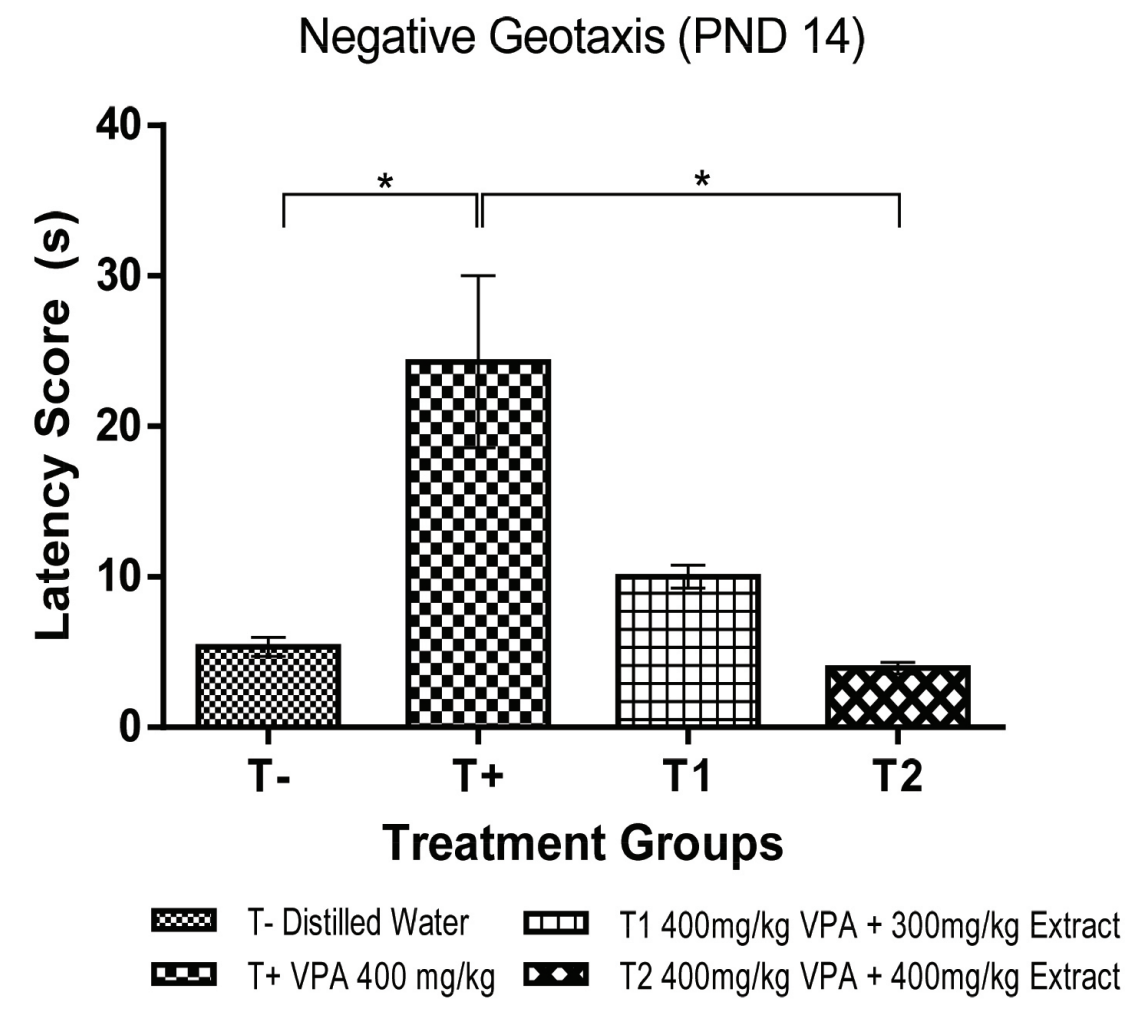

Figure 1. Mean latency scores of the negative geotactic response of mice pups administered with different treatments on PND 14 
Figure 2 displays the mean latency scores for the negative geotactic response of mice pups from different treatment groups on PND 15. T+ scored the highest mean latency scores suggesting the mice pups have autism. Statistical analyses, however, revealed that the latency scores of the treatment groups were not statistically different, $\mathrm{F}_{(3,4)}=2.513, p=0.1973$. But the mean latency scores of $\mathrm{T} 1$ and $\mathrm{T} 2$ are comparable to that of $\mathrm{T}$ - suggesting that ELEZT continued to have an effect on the animals' negative geotaxis.

\subsection{Effect of ELEZT on muscle strength}

The latency of the mice pups to grip on a wire mesh until they fall on a cushioned surface was assessed on PND 14-15.

Figure 3 displays the mean latency scores for the hanging grip wire test of mice pups on
PND 14. T2 appears to be the highest, followed by T-, T+ and T1. Due to the high variability in both $\mathrm{T} 1$ and $\mathrm{T} 2$, the One-way ANOVA showed no significant differences in the mean latent scores of the four treatment groups, $\mathrm{F}_{(3,4)}=0.9740, p=$ 0.4880 . Figure 4 presents the mean latency scores for the hanging grip wire test of mice pups on PND 15. Almost consistent with PND 14 results, T2 showed the highest latency score followed by $\mathrm{T} 1, \mathrm{~T}-$ and $\mathrm{T}+$. Due to the high variability in the data, the One Way ANOVA revealed no significant differences in the means of the latency scores of the four treatment groups, $\mathrm{F}_{(3,4)}=0.4250, p=$ 0.7460 . Though not statistically significant, $\mathrm{T} 2$ in both PND 14 and 15 appeared to have the highest endurance suggesting that the ELEZT may have ameliorated the effects of VPA. Such effects may still be biologically significant.

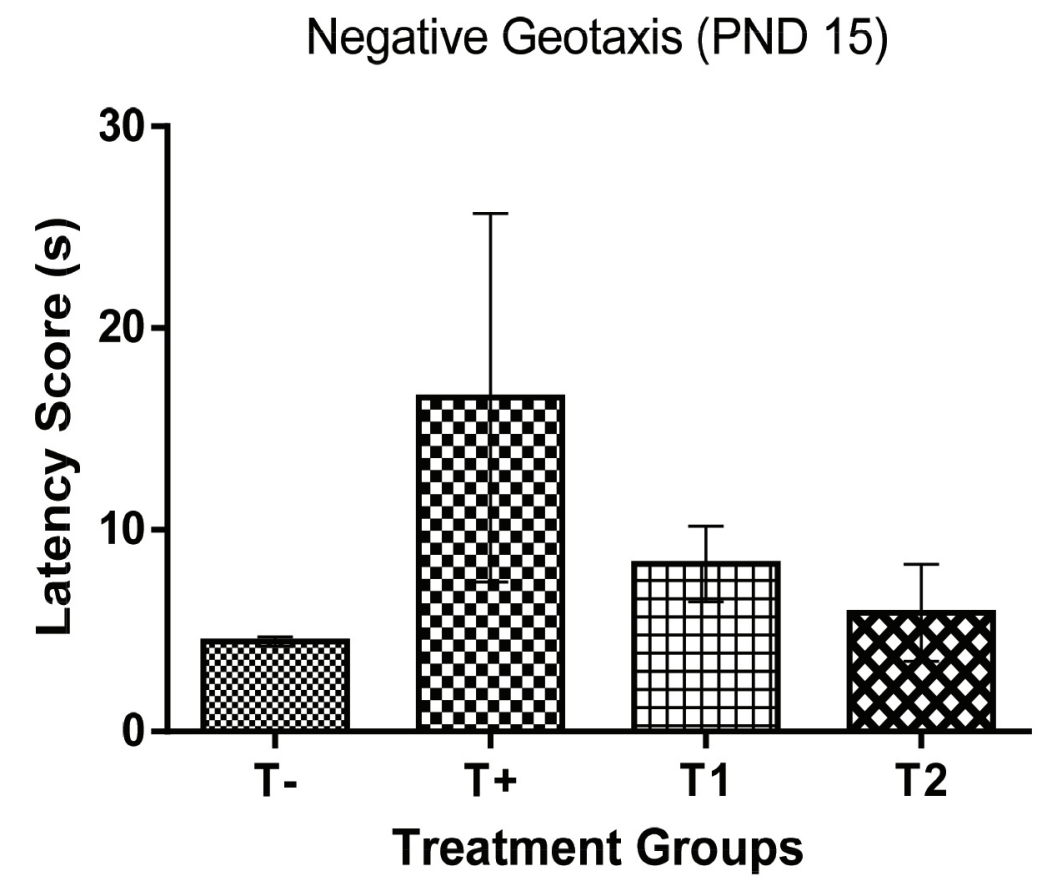

$\begin{array}{llll}\text { T- Distilled Water } & \text { T1 400 mg/kg VPA + 300 mg } / \mathrm{kg} \text { Extract } \\ \text { T+ VPA } 400 \mathrm{mg} / \mathrm{kg} & \mathrm{T} 2400 \mathrm{mg} / \mathrm{kg} \text { VPA }+400 \mathrm{mg} / \mathrm{kg} \text { Extract }\end{array}$

Figure 2. Mean latency scores of the negative geotactic response of mice pups administered with different treatments on PND 15 
Hanging Wire Grip Test (PND 14)

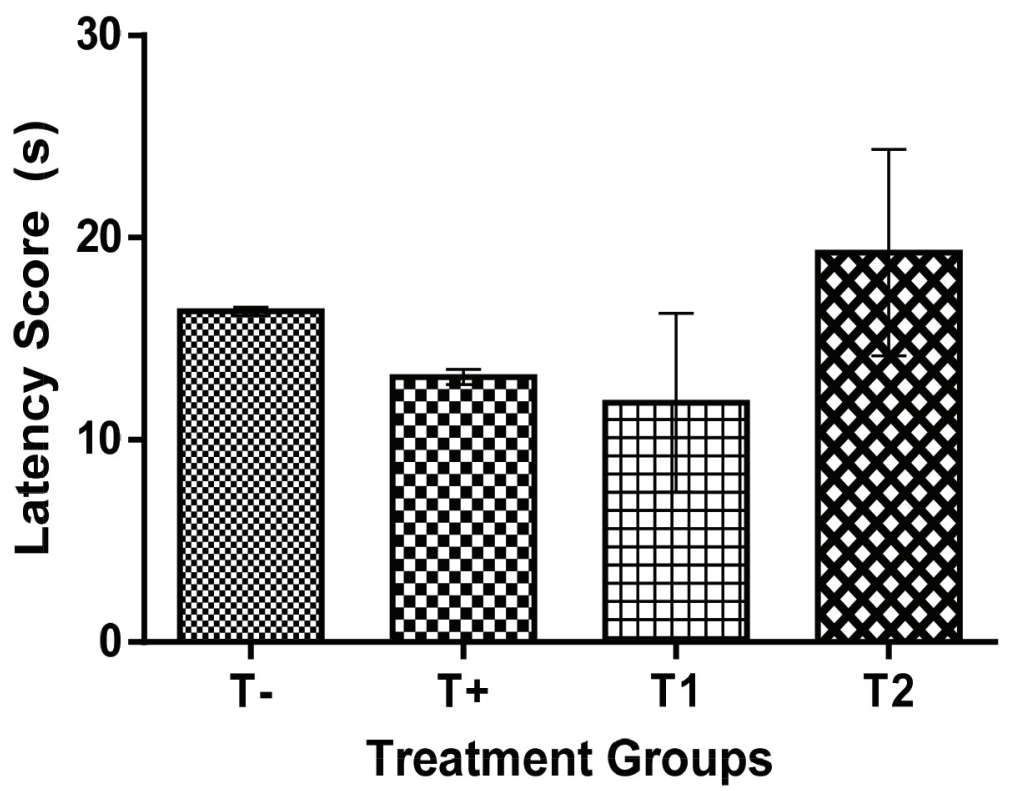

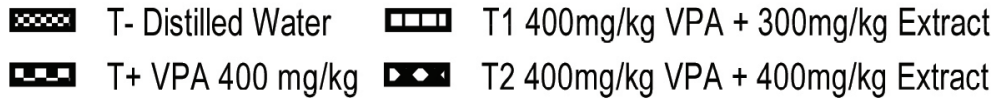

Figure 3. Mean latency scores of mice pups in hanging wire grip test administered with different treatments on PND 14

Hanging Wire Grip Test (PND 15)

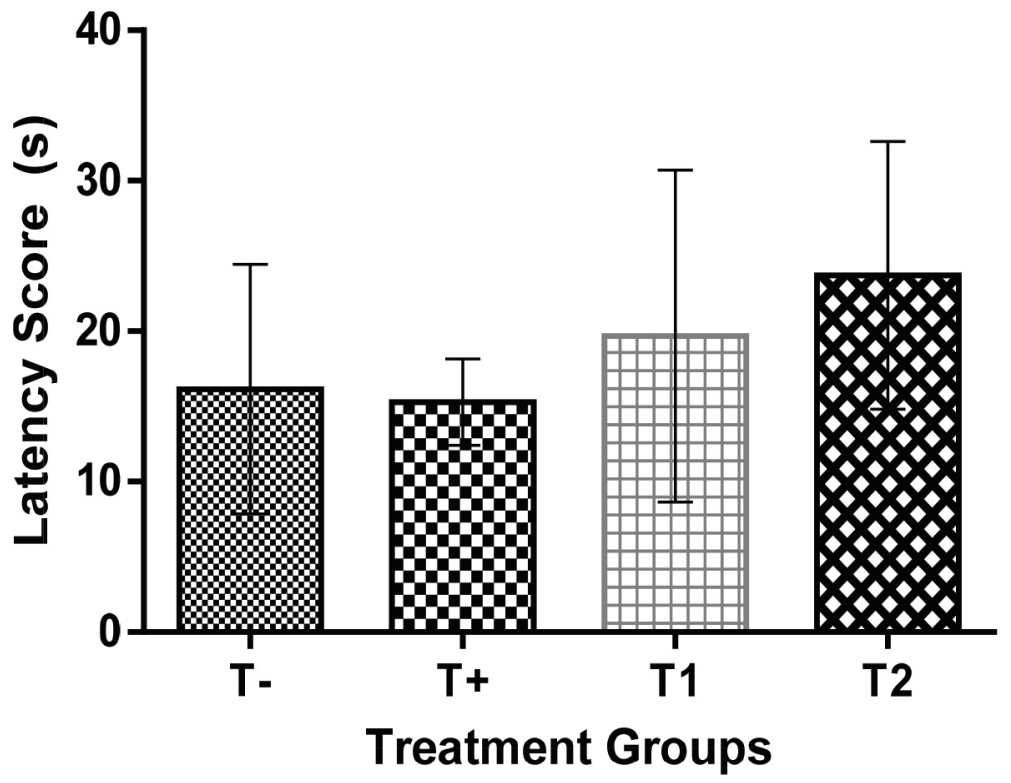

$\begin{array}{llll}\infty & \text { T- Distilled Water } \begin{array}{ll}\text { T1 } 400 \mathrm{mg} / \mathrm{kg} \mathrm{VPA}+300 \mathrm{mg} / \mathrm{kg} \text { Extract } \\ \text { T+ VPA } 400 \mathrm{mg} / \mathrm{kg}\end{array} \text { T2 } 400 \mathrm{mg} / \mathrm{kg} \mathrm{VPA}+400 \mathrm{mg} / \mathrm{kg} \text { Extract }\end{array}$

Figure 4. Mean latency scores of mice pups in hanging wire grip test administered with different treatments on PND 15 


\subsection{Effect of ELEZT on mid-air righting reflex}

The ability of the mice pups to right their body upon drop from a height of $30 \mathrm{~cm}$ onto a padded surface and land by their hindlimbs was tested on PND 14-16. Mice pups were given a positive (+) score if it was successful in two out of three trials for the test. Mice pups were given a negative (-) score if it was unsuccessful in two out of three trials. Table 2 shows the results of mid-air righting reflex of mice pups from different treatment groups on PND 14-16.

Table 2. Scores of mid-air righting reflex on PND 14-16

\begin{tabular}{ccccc}
\hline \multirow{2}{*}{ PND } & \multicolumn{5}{c}{ Treatment groups } \\
\cline { 2 - 5 } & T- & T + & T1 & T2 \\
\hline PND 14 & + & - & - & + \\
PND 15 & + & + & + & + \\
PND 16 & + & - & + & + \\
\hline
\end{tabular}

T- has shown positive mid-air righting reflex in all trial days in terms of their ability to right their body dorsoventrally to be able to land on all four paws on the ground. $\mathrm{T}+$ was given a negative assessment on PND 14 and PND 16. However, $\mathrm{T}+$ got a positive assessment on PND 15. The results of $\mathrm{T}+$ indicates that VPA has a clear effect on the mid-air righting reflex of mice pups on PND 14 and 16. Although an overall positive assessment was given on PND 15, negative assessments on PND 14 and 16 clearly suggest that postnatal exposure to VPA affects endurance, a clinical sign of autism. Wagner suggests that the acquired skill of mid-air righting have been lost to the mouse, to the point that it had regressed ${ }^{9}$. This is attributed to the dysfunction of motor coordination function in the cerebellum with the impairment of association of the efferent signals from the cerebral cortex to the cerebellum ${ }^{16}$.

T1 was given a negative assessment on PND 14 but positive on PND 15 and16. The results suggest that ELEZT is capable of ameliorating the effects of VPA to the endurance of mice pups. T2 was given a positive assessment for all trial days. This result indicates that ELEZT at $400 \mathrm{mg} /$ $\mathrm{kg}$ was able to ameliorate the effects of VPA on mid-air righting reflex of mice pups. The qualitative test revealed that the administration of VPA on mice pups impaired their ability to control the alignment of the dorsal and ventral portions of the body in mid-air. This resulted to mice pups landing on their back for being unable to control rostrocaudal alignment and body movements (See Wagner ${ }^{9}$ ).
This shows regression in the ability to right the body in mid-air of the mice pups subsequent to postnatal exposure to VPA. Since this ability is linked to cerebellar activity, it implies disruption in normal cerebellar function on motor activity due to damage to cerebellar structure ${ }^{17,18}$.

\subsection{Effect of ELEZT on the cerebellum}

The effects of ELEZT on cerebellum are shown in Figure 5. Figure 5A shows that the number and size of Purkinje cells are normal in the cerebellum of T- mice pups. Figure 5B showed that VPA significantly reduced the population and size of Purkinje cells present in the cerebellum of $\mathrm{T}+$ mice pups. Vacuolations in cell bodies of Purkinje cells are also evident suggesting the negative effects of VPA on the cerebellum. Figure 5C and 5D show that the sizes and densities of Purkinje cells were improved when compared to that of VPAtreated mice pups. Both doses of ELEZT, $300 \mathrm{mg} / \mathrm{kg}$, and $400 \mathrm{mg} / \mathrm{kg}$, significantly improved the number and size of Purkinje cells in the cerebellum of T1 and $\mathrm{T} 2$ mice pups.

Granule cells within the Granular layer (GL) are normal in the cerebellum of T- mice pups. The Molecular layer (ML) is also evidently normal. GL and ML in the cerebellum of $\mathrm{T}+$ mice pups are disrupted. In contrast, cerebellums of $\mathrm{T} 1$ and T2 mice pups showed improvements in the structure of GL and ML. These suggest that ELEZT can also mitigate the effects of VPA not only on Purkinje cells but also on GL and ML. 


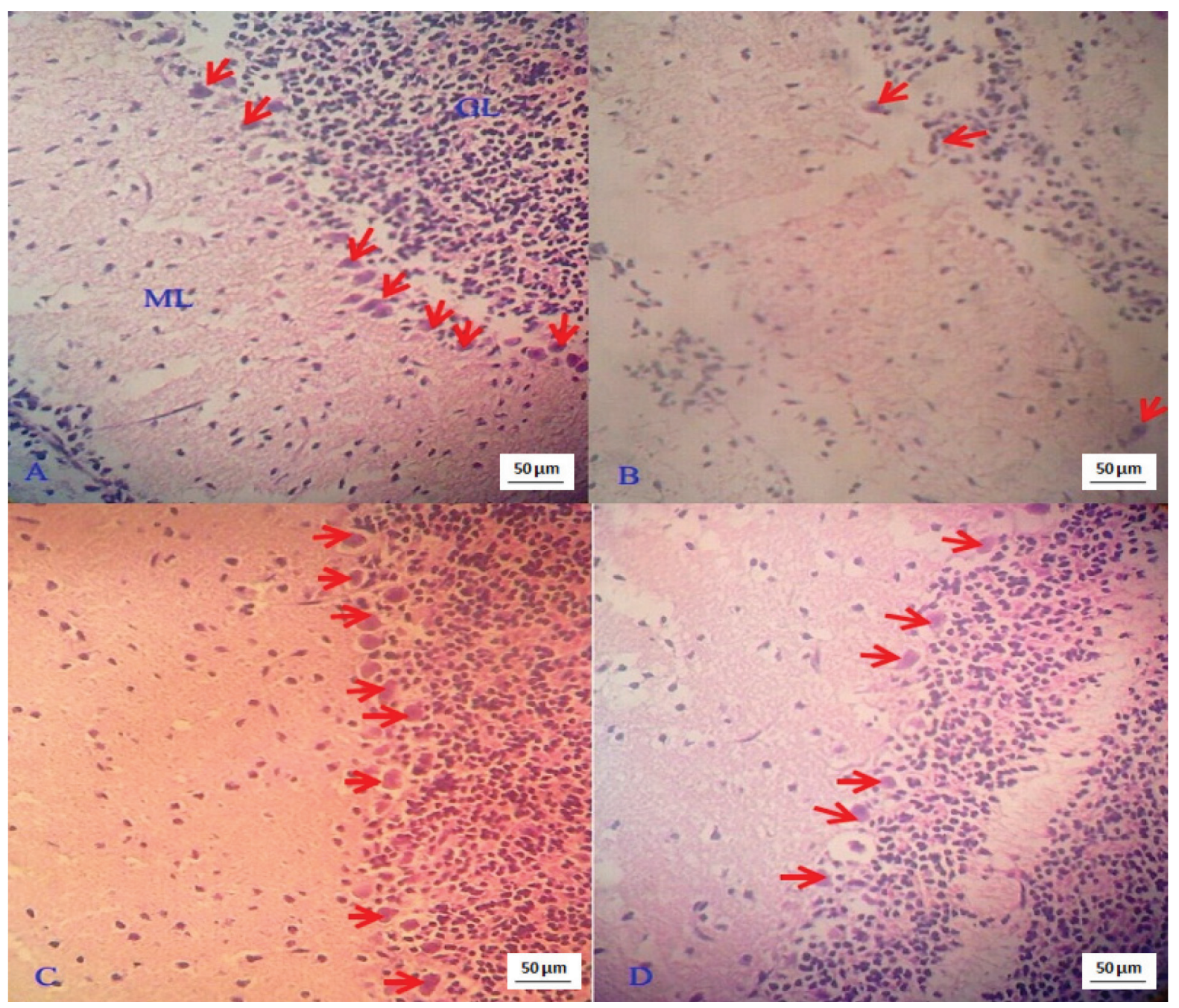

Figure 5. Effects of ELEZT on the cerebellar tissue: (A) negative control group (T-); (B) VPA-treated group (T+); (C) $300 \mathrm{mg} / \mathrm{kg}$ ELEZT + VPA (T1); (D) $400 \mathrm{mg} / \mathrm{kg}$ ELEZT + VPA (T2). Red arrows point to Purkinje cells; Molecular layer (ML); Granular layer (GL)

\section{DISCUSSION}

The study was conducted to assess the effects of postnatal exposure of VPA, a neurotoxicant, to a developing mouse cerebellum and the ameliorative potential of ELEZT through improvement of motor behaviors and cerebellar abnormalities. Since the treatment of ELEZT involved two different dosages $-300 \mathrm{mg} / \mathrm{kg}$ and $400 \mathrm{mg} / \mathrm{kg}$ - it is worthwhile comparing the effects of the two doses in terms of their ameliorating activities against VPAinduced motor behavioral aberrations and cerebellar abnormalities. The comparison between the two dosages was done in order to determine which concentration of ELEZT exhibits the most potent effect in ameliorating the pathological effects of VPA on motor behaviors and cerebellum in mice pups. Furthermore, the comparison between the two treatment dosages was made to determine if the ameliorating activities of ELEZT is dosedependent or not.

Since plants that contain polyphenols are known to possess ameliorative potentials, the restoration of the latency scores of the mice pups can serve as basis for the ameliorative effects of ELEZT by mitigating the oxidative damage in the cerebellum induced by postnatal exposure to VPA $3,11,19,20$. The genus Ziziphus is abundant in species that possess phytochemicals with antioxidant and free-radical scavenging potentials that can be attributed to the presence of several phenolic compounds ${ }^{12,21}$. Hence, Ziziphus species can be great sources of ameliorative agents against autism. 
Based on the behavioral assessments of the mice treated with VPA, previous studies have revealed that the half-life of the drug is seven (7) hours in newborn rodents and higher groups of mammals such as sheep ${ }^{22,23,24}$. Since the dosage of the oral administration of the drug was calculated based on the weight of the mice pups and this was administered prior to the behavioral testing, it can be suggested that the behavioral aberrations are pathological effects of VPA on the cerebellum and not biological artifacts.

Autistic-like behaviors are shown to be correlated with changes in the cerebellar cell number, particularly the reduction of the Purkinje cells ${ }^{25,26}$. Skills that require complex spatial organization along with working memory are shown to be compromised in children with autism ${ }^{27}$.

The results of the study revealed impaired motor behaviors and altered cerebellar histology in mice pups induced by VPA administration during the critical period of postnatal brain development. Significant reduction in the number of the Purkinje cells is parallel to the loss of granular cells, with disruption in the structure of the cell monolayer. The vulnerability of the Purkinje cells is explained by their high metabolism and excitability. The atrophies of the different cell layers of the cerebellum can be attributed to a regulatory mechanism. Purkinje cells determine the size of the granule cell population by expressing molecules necessary to the establishment of the size of the proliferative population of granule cells, which occurs in the postnatal period ${ }^{28}$.

Aberrations in motor behaviors were observed on mice pups treated with VPA based on the delayed latency in negative geotactic response and shorter latency in the hanging wire grip test. Regression in the acquired motor behavioral ability to right in mid-air was also shown. This is attributed to damaged Purkinje cells since these cells are the main output mechanism of the cerebellum. Granule cells maintain their excitation. Disruption in both of these cells can cause mismanagement of coordination of signals that leads to impaired execution of motor actions ${ }^{29}$.

The findings of the study support studies regarding the ameliorative activities of the genus Ziziphus by improving the cytological and histological parameters of the cerebellum. These were observed in mice pups treated with the different dosages of ELEZT. Motor behavior test scores of ELEZT-treated groups were shown to have improved. The ameliorative activity exerted by the extract can be attributed to the phenolic compounds present in the extract. The pharmacological activities of ELEZT were recently reported by Reyes et al. ${ }^{13}$. Phenolic compounds were also reported as neuroprotective compounds ${ }^{30}$.

Insult on the developing brain is one of the designated etiologies of $\mathrm{ASD}^{31}$. Exposure to VPA has been documented to cause abnormalities in animal models similar to those exhibited by ASDdiagnosed individuals ${ }^{9}$. Epidemiological studies have reported increasing incidence of ASD among the population over the past years, and this disorder puts a heavy burden for the family of the diagnosed individual due to the expense in management and therapy ${ }^{32}$. This preliminary study on the ameliorative capability of the $Z$. talanai is a step further in the phytomedicinal approach in the search for potential attenuative agents against the developmental deficits of ASD.

\section{CONCLUSIONS}

Based on the findings of the study, it can be concluded that ethanolic leaf extract of $Z$. talanai at $300-400 \mathrm{mg} / \mathrm{kg}$ bw exerted ameliorative activity leading to the improvement of motor behavior aberrations and cerebellar abnormalities in mice models induced by postnatal exposure to VPA. The results suggest that the $Z$. talanai ethanolic leaf extract can ameliorate the autism-like clinical signs in VPA mice model of autism. Future endeavors related to the study may be conducted to identify the potent polyphenols present in the different parts of the plant and to elucidate the mechanistic pathway for the amelioration of VPA-induced autism by $Z$. talanai ethanol extract.

\section{ACKNOWLEDGEMENTS}

The authors gratefully acknowledge the Department of Natural Sciences and Mathematics, Institute of Arts and Sciences, Mabalacat City College, Mabalacat City, Pampanga, Philippines for the support extended to the authors during the conduct of this experiment. 


\section{Conflict of interest (If any)}

The authors of this article hereby declare that there is no conflict of interests whatsoever with respect to the publication of this paper.

\section{Funding}

None to declare

\section{Ethical approval}

None to declare

\section{Article info:}

Received August 8, 2018

Received in revised form January 25, 2020

Accepted February 12, 2020

\section{REFERENCES}

1. Blatt GJ. The neuropathology of autism. Scientifica. 2012;2012: 1-16.

2. Centers for Disease Control and Prevention. Prevalence of autism spectrum disorders autism and developmental disabilities monitoring network, 14 sites, United States, 2008. Surveill Summa. 2006;61(SS03):1-19.

3. Banji D, Banji OJ, Abbagoni S, Hayath MS, Kambam S, Chiluka VL. Amelioration of behavioral aberrations and oxidative markers by green tea extract in valproate induced autism in animals. Brain Res. 2011;1410:141-51.

4. Kern JK. Purkinje cell vulnerability and autism: a possible etiological connection. Brain Dev. 2003;25(6):377-82.

5. Rice D, Barone Jr S. Critical periods of vulnerability for the developing nervous system: evidence from humans and animal models. Environ Health Perspect. 2000;108 (3):511-33.

6. Bauman M, Kemper TL. Histoanatomic observations of the brain in early infantile autism. Neurology. 1985; 35(6):866-74.

7. Palmen SJ, van Engeland H, Hof PR, Schmitz C. Neuropathological findings in autism. Brain. 2004;127(12):2572-83.

8. Gottfried C, Bambini-Junior V, Baronio D, Zanatta G, Silvestrin RB, Vaccaro T, Riesgo R. Valproic acid in autism spectrum disorder: from an environmental risk factor to a reliable animal model. In: Fitzgerald M, editor. Recent advances in autism spectrum disorders (Volume I). InTechOpen; 2013. p. 143-63.
9. Wagner GC, Reuhl KR, Cheh M, McRae P, Halladay AK. A new neurobehavioral model of autism in mice: pre-and postnatal exposure to sodium valproate. J Autism Dev Disord. 2006;36(6):779-93.

10. Pandey KB, Rizvi SI. Plant polyphenols as dietary antioxidants in human health and disease. Oxid Med Cell Longev. 2009;2(5): 270-8.

11. Morakotsriwan N, Wattanathorn J, Kirisattayakul W, Chaisiwamongkol K. Autistic-like behaviors, oxidative stress status and histopathological changes in cerebellum of valproic acid rat model of autism are improved by the combined extract of purple rice and silkworm pupae. Oxid Med Cell Longev. 2016;2016:1-10.

12. Abalaka ME, Mann E, Adeyemo, SO. Studies on in-vitro antioxidant and free radical scavenging potential and phytochemical screening of leaves of Ziziphus mauritiana $\mathrm{L}$. and Ziziphus spinachristi L. compared with ascorbic acid. J Med Genet Genomics. 2011; 3(2): 28-34.

13. Reyes AG, Peña Jr RA, Sula LF, Bañares AB. Histoprotective potentials of ethanol leaf extract of Balakat tree (Ziziphus talanai (Blanco) Merr.) against tetracycline-induced hepatotoxicity and reprotoxicity in male mice (Mus musculus L.). Int J Toxicol Pharmacol. 2016;4(2):96-104.

14. National Research Council. Guidelines for the Care and Use of Mammals in Neuroscience and Behavioral Research. Washington, DC: National Academies Press; 2003.

15. Sobaniec-Lotowska ME. Ultrastructure of Purkinje cell perikarya and their dendritic processes in the rat cerebellar cortex in experimental encephalopathy induced by chronic application of valproate. Int J Exp Pathol. 2001;82(6):337-48.

16. Zimmerman, AW, editor. Autism: current theories and evidence. New Jersey: Humana Press; 2008.

17. Tolbert DL, Ewald M, Gutting J, La Regina MC. Spatial and temporal pattern of Purkinje cell degeneration in shaker mutant rats with hereditary cerebellar ataxia. J Comp Neurol. 1995;355(4):490-507.

18. Petrosini L, Molinari M, Gremoli T. Hemicerebellectomy and motor behaviour in rats. 
Exp Brain Res. 1990;82(3):472-82.

19. Guest JA, Grant RS. Effects of dietary derived antioxidants on the central nervous system. Int J Nutr Pharmacol Neurol Dis. 2012;2(3): 185-97.

20. Kaur C, Ling EA. Blood brain barrier in hypoxicischemic conditions. Curr Neurovasc Res. 2008;5(1):71-81.

21. Choi SH, Ahn JB, Kim HJ, Im NK, Kozukue N, Levin CE, et al. Changes in free amino acid, protein, and flavonoid content in jujube (Ziziphus jujube) fruit during eight stages of growth and antioxidative and cancer cell inhibitory effects by extracts. J Agric Food Chem. 2012;60(41):10245-55.

22. Haberer LJ, Pollack GM. Disposition and protein binding of valproic acid in the developing rat. Drug Metab Dispos. 1994;22(1):113-9.

23. Yu HY, Sugiyama Y, Hanano M. Changes in pharmacokinetics of valproic acid in guinea pigs from birth to maturity. Epilepsia. 1985; 26(3):243-51.

24. Wong H, Kumar S, Rurak DW, Kwan E, Abbott FS, Riggs KW. Ontogeny of valproic acid disposition and metabolism: a developmental study in postnatal lambs and adult sheep. Drug Metab Dispos. 2000;28(8):912-9.

25. Pierce K, Courchesne E. Evidence for a cerebellar role in reduced exploration and stereotyped behavior in autism. Biol Psychiatry. 2001;49 (8):655-64.

26. Fatemi SH, Halt AR, Realmuto G, Earle J, Kist DA, Thuras P, et al. Purkinje cell size is reduced in cerebellum of patients with autism. Cell Mol Neurobiol. 2002;22(2):171-5.

27. Luna B, Minshew NJ, Garver KE, Lazar NA, Thulborn KR, Eddy WF, et al. Neocortical system abnormalities in autism: an fMRI study of spatial working memory. Neurology. 2002; 59(6):834-40.

28. Goldowitz D, Hamre K. The cells and molecules that make a cerebellum. Trends Neurosci. 1998;21(9):375-82.

29. Broussard DM. The cerebellum: learning movement, language, and social skills. Oxford, UK: John Wiley \& Sons; 2014.

30. Guest JA, Grant RS. Effects of dietary derived antioxidants on the central nervous system. Int J Nutr Pharmacol Neurol Dis. 2012;2(3): 185-97.

31. Whitney ER, Kemper TL, Bauman ML, Rosene DL, Blatt GJ. Cerebellar Purkinje cells are reduced in a subpopulation of autistic brains: a stereological experiment using calbindin-D28k. The Cerebellum. 2008;7(3): 406-16.

32. Fombonne E. The epidemiology of autism: a review. Psychol Med. 1999;29(4):769-86. 